\title{
Kebijakan Pendidikan Dalam Stabilitas Mutu Pembelajaran Anak Usia Dini Era Pandemi Disease
}

\author{
Novira Arafah', Syamsul Bahri ${ }^{2}$ \\ 1,2 Institut Pesantren KH. Abdul Chalim, Pacet Mojokerto
}

Corresponding Author: syamsulbahriabdullah7@gmail.com

\begin{tabular}{|c|c|}
\hline & ABSTRACT \\
\hline $\begin{array}{l}\text { ARTICLE INFO } \\
\text { Article history: } \\
\text { Received } \\
\text { 01 July } 2021 \\
\text { Revised } \\
\text { 10 July } 2021 \\
\text { Accepted } \\
\text { 20 July } 2021\end{array}$ & $\begin{array}{l}\text { Kajian ini dilakukan untuk menggambarkan serta mengukur : Kebijakan } \\
\text { pendidikan anak usia dini di masa pandemic, stabilitas mutu } \\
\text { pembelajaran anak usia dini pada era pandemi. Tujuan dari penelitian } \\
\text { ialah untuk menjelaskan dan menganalisis kebijakan pendidikan dan } \\
\text { mutu pendidikan pada tingkat anak usia dini di masa pandemi. penelitian } \\
\text { ini menggunakan kualitatif deskriptif dengan analisis studi pustaka. Hasil } \\
\text { dari studi pustaka ini menunjukkan : Kebijakan pendidikan pada anak } \\
\text { usia dini di era pandemi desease tergolong adaftif, terlihat dari sejauhmana } \\
\text { guru/sekolah dengan bekerjasama wali siswa dalam mengupayakan } \\
\text { terlaksananya pembelajaran melalui media yang disesuaikan guna tetap } \\
\text { memberi asupan pembelajaran di rumah bagi anak sejak dini, dan } \\
\text { stabilitas mutu pembelajaran anak usia dini pada era pandemi cukup } \\
\text { terjaga, ditinjau dari harmonisasi hubungan yang dibangun hingga tetap } \\
\text { memberikan stimulus dan respon positif bagi anak didik. Walaupun } \\
\text { sedikit mengalami kendala akibat perubahan kegiatan belajar-mengajar } \\
\text { dari sisi pra pandemi sampai saat ini. }\end{array}$ \\
\hline Keywords & Kebijakan Pendidikan, Stabilitas Mutu, Era Pandemi Disease \\
\hline How to cite & $\begin{array}{l}\text { Novira Arafah }{ }^{1} \text {, Syamsul Bahri². (2021). Kebijakan Pendidikan Dalam } \\
\text { Stabilitas Mutu Pembelajaran Anak Usia Dini Era Pandemi Disease. } \\
\text { Journal Continuous Education, 2(2). 14-22. 10.51178/ce.v2i2.224 }\end{array}$ \\
\hline
\end{tabular}

\section{PENDAHULUAN}

Meluasnya wabah Covid di seluruh penjuru dunia, termasuk negara kesatuan Republik Indonesia, turut membinasakan corak dasar-dasar kehidupan. Tidak saja sisi ekonomi yang tertimpa dampaknya secara langsung namun juga sisi pendidikan, khususnya lembaga pendidikan. Ketika situasi pandemi yang masih menunjukkan adanya trend peningkatan kasus Covid-19 ini (Wakhudin Dkk, 2020)(Arafah \& Bahri, 2020), maka sekolah harus diliburkan dan proses pembelajaran dilaksanakan secara daring, dengan menggunakan berbagai macam metode dan media (Sari, 2020). Dari hasil data yang dilakukan oleh PBB (UNESCO) 290,5 juta siswa di seluruh dunia, yang proses pembelajarannya terhambat akibat ditutupnya sekolah. Pada tingkat perguruan tinggi di AS, virus ini menunjukkan intruksinya (Agus Purwanto, 2020). Pandemi ini membawa dampak pada aspek pendidikan di Indonesia yang mana menunjukkan sekitar 45 juta siswa tidak dapat melaksanakan kegiatan belajar mengajar di sekolah sebagaimana biasanya (Azzahra, 2020).

Salah satu opsi yang dikompensasi oleh pemerintah diseluruh dunia, termasuk di Indonesia dalam penanggulangan pandemi ini adalah dengan diterapkan pembatasan kegiatan 
sosial setiap masyarakat, mulai dari istilah lock down, hingga PSBB dimana bertujuan agar menghimbau masyarakat tetap berada dirumah untuk memutus mata rantai wabah(Muh. Hasrul, 2019). Dengan adanya pemberlakuan ini maka seluruh kegiatan spontan berubah dan menjadi terganggu, salah satunya sekolah, mau tidak mau aktivitas sekolah digantu dengan alternative belajar di rumah melalui bimbingan orang tua dan menggunakan pembelajaran online (Muamar Al Qadri, 2021). Kebijakan PSBB sudah ditetapkan oleh pemerintah dalam PP Nomor 21 tahun 2020 yang di pertegas pada PerMenKes No 9 tahun 2020 (Sangputri Sidik, 2020).

Sejalan dengan itu, perkembangan status darurat Covid-19 yang mempermudah guru dan anak, serta mengutamakan pembelajaran berbasis nilai karakter, maka Kemendikbud melaksanakan langkah-langkah penyesuaian pembelajaran melalui Surat Edaran Nomor 2 Tahun 2020 (Penanggulangan bencana Covid-19 di lingkungan Kemendikbud), Nomor 3 Tahun 2020 (Pencegahan Covid-19 pada Satuan Pendidikan), dan Nomor 4 Tahun 2020 tentang pelaksanaan kebijakan proses school from home (SFH) (Fieka Nurul Arifa, 2020).

Salah satu lembaga yang tidak luput dari kebijakan pendidikan ini adalah lembaga PAUD, dimana seluruh aktivitas sekolah juga terhenti dan kepala madrasah menetapkan untuk mengikuti aturan pemerintah. Menurut Zimmermann dan Curtis, anak-anak merupakan rentang usia yang teramat mudah terhadap penularan covid dari beberap sisi, seperti lingkungan dan sekitarnya. Beberapa anak yang terinfeksi penyakit ini acap kali tidak teridentifikasi gejalanya (Alif Yanuar Zukmadini dkk, 2020). Oleh karena itu, harus ditindaklanjuti oleh kepala lembaga pendidikan PAUD dalam mengambil kebijakan dan membuat keputusan melalui program pendidikan yang tetap terselenggara untuk anak usia dini agar tetap terlayani, terutama bagaimana mengimplikasikan orang tua agar efektif dalam pemberian eksitasi atau rangsangan kepada anak (Nur Hazizah, 2020). Anak usia dini tidak mungkin melakukan pembelajaran daring seperti dalam lembaga pendidikan diatas PAUD, karena di masa usia anak sejak dini ialah karakter yang membutuhkan sentuhan yang penuh hangat serta interaksi melalui verbal maupun non verbal. (Cucu Jajat Sudrajat dkk, 2021).

Menurut NEST TEAM, PAUD sebagai proses tumbuh kembang anak yang di mulai dari usia 0-8 tahun, mencakup ranah fisik dan nonfisik yakni memberikan stimulus terhadap perkembangannya, baik dari segi mental, aspek intelektual, sikap emosional dan moral, maupun sosial. Keseluruhan sisi yang dimiliki diberdayakan melalui program PAUD yaitu pembelajaran yang dikemas dengan aktivitas menyenangkan dan dilakukan sambil bermain. Potensi dasar dan bawaan seorang anak tidak akan mengalami perkembangan apabila tanpa adanya rangsangan dari pendidik (guru) dan orang tua selaku guru di rumah. Lembaga PAUD sebagai pelopor perkembangan dasar anak yang berdampak pada proses kehidupannya di masa yang akan datang (Ika Budi Maryatun, 2016).

Dalam mewujudkan perkembangan PAUD, peran pemimpin sangat penting, dalam hal yakni pimpinan utama sekolah. Seorang pimpinan dibutuhkan agar PAUD dapat menjadi layanan terbaik dan berkualitas prima bagi anak didik dan stakeholders. Sebab, lembaga pendidikan sekolah sesungguhnya berkaitan dengan jaringan jaringan kemasyarakatan (Abdul hakim Jurumiah dan Husen Saruji, 2020). Virus yang mewabah ini sangat berdampak pada layanan sekolah kepada masyarakat mulai dari sisi perencanaan, pelaksanaan dan penerapan serta proses evaluasi. Pimpinan sebagai pengambil keputusan tertinggi harus berupaya melakukan strategi khusus dalam proses pendidikan dan pencapaian mutu sekolah, agar dapat beralan sesuai dengan yang diharapkan (Ekosiswoyo, 2007).

Seorang pemimpin harus mampu memobilisasi seluruh manajemen agar mutu pendidikan tetap diutamakan dan terjaga, ini merupakan pekerjaan yang harus menjadi fokus atau prioritas 
utama dari kepala sekolah sebagai penanggungjawab yang menjadi tolak ukur keberhasilan sebuah lembaga (Sophia Azhar, 2017). Dalam menjaga stabilitas mutu pendidikan di masa pendemi, kepala sekolah PAUD konsisten dalam memberikan layanan pendidikan bagi anak usia dini, dan menjaga kualitas dan mutu pendidikan anak adalah cara agar anak terus berkembang secara optimal sebagaimana mestinya berdasarkan tahapan usia perkembangannya. Hal itu dapat dikembangkan melalui program perencanaan dimana mereka mengembangkan gaya belajar model baru dengan pemberian pelatihan bagi guru-guru untuk dapat cakap menggunakan teknologi di masa pembelajaran virtual saat ini, pemberian kuota (subsidi) agar proses belajar-mengajar tetap terjalin serta kerjasama antar orang tua dalam masa pembelajaran di rumah untuk evaluasi hasil belajar anak didik guna tetap menjaga kestabilan mutu pendidikan

\section{METODE PENELITIAN}

Metode dari penelitian ini ialah kajian pustaka. Diperoleh dengan mencari referensi berupa teori yang relevan dengan permasalahan atau fenomena yang ditemukan. Dengan cara mencari bukti-bukti yang mendukung masa pembelajaran anak usia dini di era pandemic disease sebanyak lebih dari 25 artikel dan didukung oleh informasi dari media massa, Tulisan ini bertujuan untuk mengkaji dan melihat bagaimana kebijakan pendidikan dengan tetap menjaga stabilitas mutunya di tengah pandemic disease yang melanda.

\section{HASIL PENELITIAN DAN PEMBAHASAN}

\section{Kebijakan Pendidikan}

Kebijakan pendidikan menggunakan pendekatan metodologis dan pendekatan konseptual. Pada intinya metodologi adalah seluruh prosesnya secara berurutan dilakukan dengan cara mengorganisasikan analisis kebijakan dalam suatu sistem dan mekanisme yang institusional. Ilmu perekayasaan sosial yang memiliki arti ilmu yang menemukan dan mendapat manfaat dari rancangan dan penemuan dalam bermacam disiplin ilmu sosial merupakan analisis dalam kebijakan yang bertujuan memecahkan persoalan yang muncul dalam suatu kebijakan (Ace Suryadi dan Dasim Budimansyah, 2009).

Kebijakan didefinisikan oleh Harman yakni spesifikasi implisit atau eksplisit yang merupakan beberapa aktivitas yang harus yang diikuti, khususnya permasalahan serius dan dianggap penting dalam mencapai sasaran yang diharapkan. Hogwood dan Gunn, mengungkapkan bahwa kebijakan merupakan gambaran ekspresi umum dari kondisi dan keadaan yang diharapkan. Kebijakan merupakan suatu keadaan yang dikembangkan sebagai respon terhadap suatu masalah yang telah ditentukan arahnya menuju tujuan yang ingin dicapai (Fattah, 2012).

Terdapat tiga komponen kebijakan yang harus ada dalam sebuah kebijakan , yakni (1) pelaku kebijakan, (2) lintasan kebijakan, dan (3) kebijakan bersama. Konteks khusus yang berupa kejadian-kejadian yang terjadi di lingkungan sekitar dan issue factor kebijakan yang merupakan proses bersifat dialektis dan dikeluarkan dalam suatu kebijakan yang tidak terpisahkan dari praktiknya. 


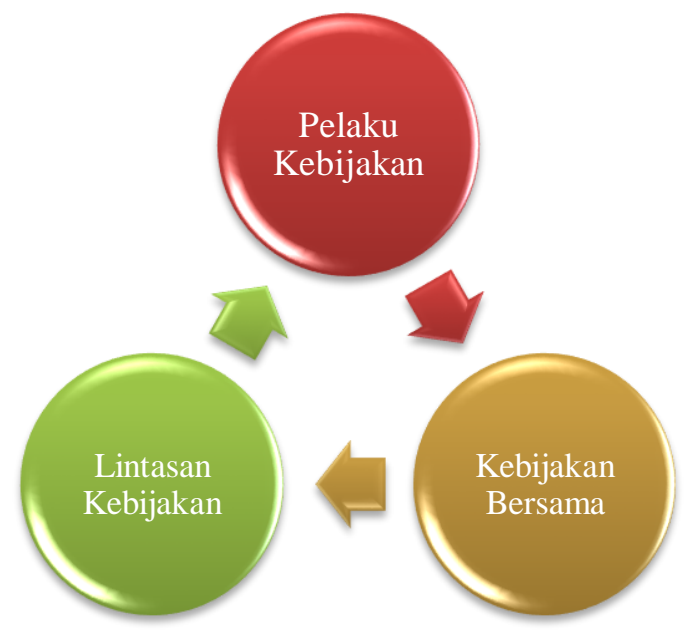

Gambar 1. Tiga Aspek Sistem Kebijakan (Syafaruddin, 2008)

Secara mikro, Pimpinan PAUD berkewajiban atas kebijakan pendidikan, yang secara langsung berkaitan erat terhadap pengelolaan proses pembelajaran(Nugraheni Dwi Agustin, 2015). Dalam hal ini, kebijakan menunjukan kegiatan yang dapat dilakukan untuk mencapai target atau sasaran. Bisa saja dalam satu tujuan membutuhkan beberapa kegiatan begitupun sebaliknya, beberapa tujuan membutuhkan satu macam kegiatan (Ali Imron, 2012). Untuk itu, keterlibatan antara civitas lembaga PAUD dan stakeholders harus saling bersinergis, harmonis dan konsisten sehingga pengguna pendidikan, dalam hal ini anak didik PAUD dapat tetap merasakan pembelajaran semestinya tanpa terkecuali.

\section{Mutu dalam Konteks Pendidikan}

Mutu dalam konteks pendidikan saat ini dapat dilihat dari sejauhmana kompetisi bersaing antar lembaga pendidikan yang semakin hari semakin gencar. Dimana, seperti menunjukkan ajang perlombangan dengan menual mutu yang dimiliki oleh masing-masing lembaganya (Novira Arafah, Zakariyah, 2020). Dinamisnya konteks mutu pendidikan merupakan wujud dari kepuasan, yang dapat terlihat dari sisi produsen dan pengguna. Mutu sudah selayaknya memiliki sifat yang dinamis dikarenakan tingkat kepuasan akan selalu mengalami perubahan pula sesuai dengan perkembangan zaman. Itulah mengapa konsep mutu dikaitkan sebagai contonous quality improvement, yaitu upaya perbaikan berkelanjutan (Yuli Dwi Indahwati, 2018).

Mundir merangkum lima karakteristik mutu, yakni:

1. Kegiatan pengembangan secara berkelanjutan, yaitu pencapaian yang diharapkan bukan hanya sekedar baik melainkan sangat baik;

2. Fokus pada proses, yaitu menghasilkan barang berupa jasa;

3. Pengembangan mutu secara keseluruhan, yaitu melakukan proses, penanganan complain secara baik dan sopan, serta menerima masukan dan arahan;

4. Pengukuran yang akurat, yakni mengukur kegiatan penting dalam organisasi, seperti: mengidentifikasi, mengukur dan memecahkan masalah;

5. Pemberdayaan sumber daya manusia, yaitu mengembangakan dalam kaitan untuk menemukan dan menyelesaikan masalah (Ari Kartiko, 2019).

Dari beberapa point di atas, dapat dikatakan inti dari sebuah lembaga merupakan jasa pelayanan yang mewadahi anak dengan memberikan akses seluas-luasnya terhadap anak untuk berkreasi dan mengasah kreativitasnya hingga menjadikannya memiliki soft skill yang kemudian dapat dikembangkan oleh bantuan tenaga ahli, dalam hal ini yakni pendidik berkolaborasi dengan orangtuanya. 


\section{Pembelajaran Anak Usia Dini}

Dalam pandangan psikologi kontemporer diisyaratkan bahwa belajar merupakan aktivitas konstruksi pengetahuan yang terjadi from within (dari dalam). Pembelajaran di dapat dari aktivitas dua arah yang dilakukan oleh di pengajar dan pembelajar serta terdapat aktivitas dimana disebut dengan proses pembelajaran, baik secara tingkah dan laku, dan penyampaian informasi berupa pemberian materi (Eny Kusumastuti, 2009). Damanik memaparkan dalam hasil penelitian yang dilakukannya terhadap lembaga pendidikan, bahwa pengaruh kondisi lingkungan belajar sangat besar terhadap motivasi untuk belajar. Lingkungan belajar harus tercipata dalam nuasa positive sebagaimana di sekolah, untuk menumbuhkan motivasi siswa dalam belajar. Jika lingkungan sekolah sangat kondusif serta menumbuhkan keinginan belajar siswa tinggi, maka hasil yang dicapai akan meningkat pula (Azizah Nurul Fadlilah, 2021). Untuk itu, guru perlu bersikap baik, santun dan menghargai. Dimana hal tersebut dimaksudkan agar seorang anak tidak merasa tertekan untuk mencoba/beralih ke arah yang disukai. Hakikatnya anak memiliki keingintahuan yang tinggi untuk menemukan keinginannya sehingga mencapai rasa puas dalam dirinya. (M. Agung Hidayatulloh, 2014).

Seorang pendidik memebutuhkan komunikasi yang luas terhadap peserta didik untu memproses transformasi pesan berupa ilmu pengetahuan dan teknologi. Hal ini bertujuan agar anak tersebut mampu mengerti hingga memahami serta mendapat menambah wawasan IPTEK untuk membentuk perubahan terhadap tingkah laku kepada yang lebih baik. Bertrand berpendapat ada 5 komponen keefektifan komunikasi terhadap media, meliputi: (1)daya tarik , (2) pemahaman, (3) penerimaan (4) keterlibatan, and (5) persuasi (Nurdin dan La Ode Anhusada, 2020).

Menstimulasi rasa keindahan (tahap estetis) merupakan tahapan awal dalam pembentukan karaktek bagi anak. Fungsi dari estetis ini adalah untuk memperhalus perilaku/ budi. Umumnya anak usia dini memperoleh ini melalui seni rupa, musik, dan tari. Sebab, hal ini dapat mengasah aspek keindahan dan seni. Di tahap selanjutnya, anak didik diajarkan dengan mencontohkan keteladanan, seperti melakukan perilaku baik (perilaku meniru). Proses ini sangat menjadi ciri khas perilaku pada anak dikarenakan kemampuan kognitif anak belum mampu mengasah fenomena alam di sekitarnya, Tahap selanjutnya, melalui sikap pembiasaan. Setelah anak terbiasa dengan stimulasi yang telah diberikan sebelumnya (Prasanti \& Fitriani, 2018).

Berikutnya dengan proses implementasi, yakni pelaksanaan dan penerapan yang pada akhirnya bermuara menjadi suatu pole kebiasaan. Anak terus melakukan hal-hal baik, dalam kesehariannya hingga membentuk suatu karakter terhadap diri. Hal ini dilakuakn secara kontinuitas dengan tidak memaksakan anak secara berlebih (menekan, membebani, dan memaksa) kehendak pada anak. Proses pembiasaan dilakukan dengan tetap mengedepankan kesanggupan dan kemauannya. Sebab sikap moral yang tumbuh karena paksaan, sejatinya tidak akan menjadi pondasi yang kuat untuk melekat pada kepribadian anak (Hewi \& Asnawati, 2020).

Selanjutnya yakni fase kognitif. Fase ini dilakukan apabila sisi kognitinya mula mencapai matang. Perilaku baik yang harus dilakukan dan layak menjadi pilihannya akan dapat dipahami dengan lebih mudah saat kematangan kognitif yang dimilikinya sudah tumbuh. Proses ini memerlukan perbincangan yang spesifik mengenai pembahasan moralitas sebab anak sudah terlihat cukup siap menerima pembicaan khusus yang bersifat mendalam, dimana untuk mendapat respons dan perhatian mereka terkadang beberapa trick menarik perlu digunakan agar tidak menimbulkan kejenuhan karena menyita waktu beberapa lama

Berikut cara ringkas mengetahui karakter anak, ditunjukkan pada gambar di bawah ini: 


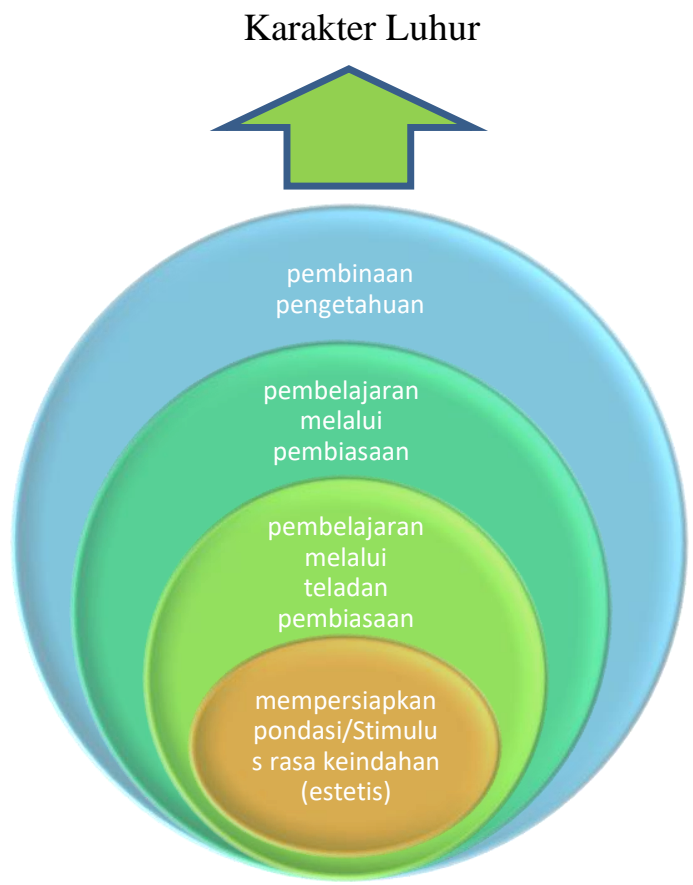

Gambar 2. Tahapan Pembinaan Karakter (Yeni Rachmawati, n.d.)

\section{Stabilitas Mutu jenjang Pendidikan Anak Usia Dini era Pandemi Disease}

Pandemi disease merupakan masa yang sangat mendebarkan yang tak terbayangkan sebelumnya hingga harus dijalani dengan kerelaan hati. Utamanya dalam hal mutu dilembaga pendidikan, baik pada jenjang usia dini, usia dasar, dan usia menengah atas hingga perguruan tinggi. Dalam dirkursus kali ini, yakni jenjang PAUD dimana rentang usia antara 0-6 tahun, masih sangat rentan dan belum bisa dipercayakan sepenuhnya atas dirinya sendiri.

Di era digital/IT memberikan penawaran kemudahan dalam dunia pendidikan, dapat ditinjau dari sesi pemberian materi pembelajaran. Dengan demikian, upaya ini sangat mendorong untuk mempertajam pemanfaatan ICT (Information and Communication Technology). ICT merupakan suatu media untuk pembelajaran yang digunakan untuk memberi bahan pembelajaran (Mariance Pah, 2016).

Menanggapi pandemi COVID-19, pada 18 Maret 2020, 107 negara telah menerapkan penutupan sekolah, Tidak diketahui apakah tindakan tersebut efektif. Masa pendemi harus mengubah seluruh pola kehidupan masyarakat terutama dalam aspek pendidikan. Walaupun kita sudah masuk pada masa era digital namun tidak seluruh tingkat dan daerah sudah mampu untuk go digital dalam pelaksanaan pendidikan. Namun pada masa pandemi ini metode atau strategi pembelajaran daring inilah yang digunakan sebagai penyambung kegiatan belajar semasa peliburan kegiatan belajar, untuk itu perlunya mengubah pola belajar mengajar yang ada di masyarakat kita (Russell M Viner, 2020). Covid-19 memberikan dampak pada cara mendidik generasi masa depan, setidaknya terdapat empat cara. Ini mencakup proses pendidikan yang semakin saling terkait di seluruh dunia, mendefinisikan kembali apa peran pendidik sebenarnya, dan mengajarkan pentingnya keterampilan hidup di masa depan, dan peran teknologi yang lebih luas dalam mendukung pendidikan (Zhou et al., 2020).

Nadiem Makarim selaku Kemendikbud telah mengungkapkan bolehnya memulai pembelajaran yang semula tatap muka, menjadi PJJ, dan kembali memulai aktivitas pembelajaran seperti masa pra pandemi pada daerah yang termasuk zona 3T. Untuk itu, kepala sekolah selaku pemegang kebijakan pendidikan diharapkan mulai menstabilitasi lembaganya 
guna tetap berjalannya proses pendidikan bagi anak-anak bangsa. Berikut ini soft skill yang harus dimiliki sebagai pendidik anak usia dini, agar pembelajaran di rumah berjalan efektif dan efisien dengan memanfaatkan teknologi, yaitu: (1) Guru diharuskan beradaptasi dengan kemajuan teknologi untuk menunjang pembelajaran dari rumah. Kedua, guru harus mampu berkreasi dan inovatsi terhadap materi ajar, sesuai aturan Kemendikbud No. 4 Tahun 2020, target PJJ/daring tidak terfokus untuk menyelesaikan kurikulum. Jadi, pembelajaran dapat diarahkan untuk peningkatan kecakapan anak. Ketiga, guru dituntut memiliki skill komunikasi yang luwes kepada orang tua/wali agar pengasuhan berjalan secara baik. Sebab bertalian erat dengan upaya tumbuh kembang anak secara maksimal walau ditengah wabah pandemi. Keempat, feed-back atau timbal balik berguna untuk membantu orangtua dalam menerapkan praktek pembelajaran di rumah (pengelola web kemdikbud, 2020).

\section{KESIMPULAN}

Hasil akhirnya ialah Kebijakan pendidikan pada anak usia dini di masa pandemi tergolong adaftif, terlihat dari sejauhmana guru/sekolah dengan bekerjasama wali siswa dalam mengupayakan terlaksananya pembelajaran melalui media yang disesuaikan guna tetap memberi asupan anak sejak dini. Mengenai stabilitas mutu pembelajaran anak usia dini pada era pandemi cukup terjaga, ditinjau dari harmonisasi hubungan yang dibangun hingga tetap memberikan stimulus dan respon positif bagi anak didik. Walaupun beberapa fakta di lapangan, sekolah tetap mempertahankan eksistensinya dengan berbagai kemudahan yang diberikan dan dianjurkan oleh pemerintah. Mengalihfungsikan sekolah dengan PJJ dan memaksimalkan penggunaan ICT. Dampaknya tetap tak luput dari istilah pro dan kontra di khalayak masyarakat. Bagaimana tidak? Sementara siswa/I jenjang PAUD ini membutuhkan dampingan penuh dari orang tuanya selama PJJ, tetapi beberapa aktivitas menekan orangtua hingga terkadang menimbulkan penegasan yang cukup serius, bentakan yang dapat merusak mental anak sendiri. Akibatnya, kurang optimal dalam pelaksanaan pembelajarannya. Untuk itu, anak, orang tua, dan lembaga harus saling berbesar hati dalam melaksanakan tatanan baru yang akan menjadi gaya baru pula pada elemen pendidikan baik saat pandemi maupun pasca pandemic disease.

\section{DAFTAR PUSTAKA}

Abdul hakim Jurumiah dan Husen Saruji. (2020). Sekolah Sebagai Instrumen Konstruksi Sosial di Masyarakat (School As a Social Construction Instrument In The Community). ISTIQRA': Jurnal Pendidikan Dan Pemikiran Islam, 7(2), 1-9. http://jurnal.umpar.ac.id/index.php/istiqra/article/view/492

Ace Suryadi dan Dasim Budimansyah. (2009). Paradikma Pembangunan Pendidikan Nasional, Konsep, Teori, Dan Aplikasi Dalam Analisis Kebijakan Publik. Widaya Akasara Press.

Agus Purwanto. (2020). Studi Eksploratif Dampak Pandemi COVID-19 Terhadap Proses Pembelajaran Online di Sekolah Dasar. EduPsyCouns: Journal of Education, Psychology and Counseling, 2(1), 1-12. https://ummaspul.e-journal.id/Edupsycouns/article/view/397

Ali Imron. (2012). Manajemen Peserta Didik Berbasis Sekolah. Bumi Aksara.

Alif Yanuar Zukmadini dkk. (2020). Edukasi Perilaku Hidup Bersih dan Sehat ( PHBS ) dalam. Jurnal Pengabdian Magister Pendidikan IPA, 3(1), 68-76. https://doi.org/10.29303/jpmpi.v3i1.440

Arafah, N., \& Bahri, S. (2020). Peningkatan Human Capital Dalam Proses Pembelajaran di Era $\begin{array}{lllll}\text { New Normal. Jurnal Manajemen } & \text { Bisnis, }\end{array}$ 
https://doi.org/10.38043/jmb.v17i3.2539

Ari Kartiko. (2019). Manajemen Mutu Pendidikan. Bening Pustaka.

Azizah Nurul Fadlilah. (2021). Strategi Menghidupkan Motivasi Belajar Anak Usia Dini Selama Pandemi COVID-19 melalui Publikasi. Jurnal Obsesi : Jurnal Pendidikan Anak Usia Dini, 5(1), 373-384. https://doi.org/10.31004/obsesi.v5i1.548

Azzahra, N. F. (2020). Mengkaji Hambatan Pembelajaran Jarak Jauh di Indonesia di Masa Pandemi Covid-19. Center for Indonesians Policy Studies, 19(2), 1-9. https://repository.cips-indonesia.org/id/publications/309163/mengkaji-hambatanpembelajaran-jarak-jauh-di-indonesia-di-masa-pandemi-covid-19

Cucu Jajat Sudrajat dkk. (2021). Strategi Kepala TK dalam Meningkatkan Mutu Pendidikan pada Masa Pandemi Covid 19 Abstrak. Jurnal Obsesi : Jurnal Pendidikan Anak Usia Dini, 5(1), 508-520. https://doi.org/https://doi.org/10.31004/obsesi.v5i1.582

Ekosiswoyo, R. (2007). Kepemimpinan kepala sekolah yang efektif kunci pencapaian kualitas pendidikan. Jurnal Ilmu Pendidikan, 14(2), 76-82. https://doi.org/http://dx.doi.org/10.17977/jip.v14i2.24

Eny Kusumastuti. (2009). PERUBAHAN PERILAKU KECERDASAN EMOSIONAL ANAK USIA DINI MELALUI PENDIDIKAN SENI TARI. Harmonia: Journal of Arts Research and Education, 9(2), 1-16. https://doi.org/10.15294/harmonia.v9i2.639

Fattah, N. (2012). Analisis Kebijakan Pendidikan. PT Remaja Rosdakarya.

Fieka Nurul Arifa. (2020). Tantangan Pelaksanaan Kebijakan Belajar Dari Rumah Dalam Masa Darurat Covid-19. Info Singkat; Kajian Singkat Terhadap Isu Aktual Dan Strategis, $X I I(7 / I)$, $13-18$. https://scholar.google.co.id/scholar?hl=id\&as_sdt=0\%2C5\&q=TANTANGAN+PELAKS ANAAN+KEBIJAKAN+BELAJAR+DARI+RUMAH+DALAM+MASA+DARURAT+ COVID-19\&btnG=

Hewi, L., \& Asnawati, L. (2020). Strategi Pendidik Anak Usia Dini Era Covid-19 dalam Menumbuhkan Kemampuan Berfikir Logis. Jurnal Obsesi: Jurnal Pendidikan Anak Usia Dini. https://doi.org/10.31004/obsesi.v5i1.530

Ika Budi Maryatun. (2016). Peran pendidik paud dalam membangun karakter anak. Jurnal Pendidikan Anak, 5(1), 747-752. https://doi.org/https://doi.org/10.21831/jpa.v5i1.12370

M. Agung Hidayatulloh. (2014). Lingkungan Menyenangkan dalam Pendidikan Anak Usia Dini : Pemikiran Montessori. Nadwa: Jurnal Pendidikan Islam, 8(1), 139-154. https://doi.org/http://dx.doi.org/10.21580/nw.2014.8.1.574

Mariance Pah. (2016). Pengembangan Media Pembelajaran Berbasis ICT Mengacu Kurikulum SD 2013 Subtema Bersyukur Atas Keberagaman Untuk Siswa Kelas IV Sekolah Dasar Negeri Kalasan 1. Universitas Sanata Dharma.

Muamar Al Qadri, S. W. (2021). Pengaruh Home Visit Method Terhadap Hasil Belajar Luring di Masa Pandemi COVID-19 Pada Mata Pelajaran Al Qur'an Hadits (Studi Kasus Siswa Kelas VIII MTS Jam'iyah Mahmudiyah Tanjung Pura Langkat). Continuous Education: Journal of Science and Research, 2(1), 61-71. https://doi.org/10.51178/ce.v2i1.187

Muh. Hasrul. (2019). Aspek Hukum Pemberlakuan Pembatasan Sosial Berskala Besar (PSBB) Dalam Rangka Penanganan Corona Virus Disease 2019 (Covid-19). Legislatif, 3(2), 385398. https://journal.unhas.ac.id/index.php/jhl/article/view/10477

Novira Arafah, Zakariyah, R. C. (2020). Kualitas Pelayanan Pendidikan Islam Dalam Mencapai Kepuasan Pelanggan/Peserta Didik di Mts Pacet Mojokerto. Inovatif, 6(2), 1-19. http://jurnal.staih.ac.id/index.php/inovatif/article/view/185 
Nugraheni Dwi Agustin. (2015). Gaya Kepemimpinan Kepala Sekolah dalam Meningkatkan Kinerja Pendidik dan Pengelolaan Pendidikan di SDIT Insan Mulia Wonosobo [Pascasarjana UIN Sunan Kalijaga]. http://digilib.uin-suka.ac.id/id/eprint/17484

Nur Hazizah. (2020). Leadership Headmaster in Improving the. SPEKTRUM Jurnal Pendidikan Luar Sekolah (PLS), 8(2), 142-146. https://doi.org/10.24036/spektrumpls.v8i2.109155

Nurdin dan La Ode Anhusada. (2020). Efektivitas Pembelajaran Online Pendidik PAUD di Tengah Pandemi Covid 19. Jurnal Obsesi: Jurnal Pendidikan Anak Usia Dini, 5(1), 686-697. https://doi.org/10.31004/obsesi.v5i1.699

pengelola web kemdikbud. (2020, September 8). Kemendikbud Jadikan Peringatan HAI sebagai Momentum Perubahan Paradigma Pendidikan. https://www.kemdikbud.go.id/main/blog/2020/09/kemendikbud-jadikan-peringatan-haisebagai-momentum-perubahan-paradigma-pendidikan

Prasanti, D., \& Fitriani, D. R. (2018). Pembentukan Karakter Anak Usia Dini: Keluarga, Sekolah, Dan Komunitas? (Studi Kualitatif tentang Pembentukan Karakter Anak Usia Dini Melalui Keluarga, Sekolah, dan Komunitas). Jurnal Obsesi : Jurnal Pendidikan Anak Usia Dini, 2(1), 13. https://doi.org/10.31004/obsesi.v2i1.2

Russell M Viner, D. (2020). School closure and management practices during coronavirus outbreaks including COVID-19: a rapid systematic review. The Lancet Child \& Adolescent Health, 4(5), 397-404. https://doi.org/https://doi.org/10.1016/S23524642(20)30095-X

Sangputri Sidik. (2020). Analisis Dampak Kebijakan Pembatasan Waktu Operasional Pasar Di Kabupaten Minahasa Akibat Penanggulangan Covid-19. JISIP (Jurnal Ilmu Sosial Dan Pendidikan), 4(3), 52-59. https://doi.org/http://dx.doi.org/10.36312/jisip.v4i3.1160

Sari, N. (2020). Problematika Pelaksanaan Pembelajaran Daringmasa Pandemic Covid-19 di MIN 3 Medan. Journal Of Education And Teaching Learning (JETL), 2(3), 44-57. https://doi.org/10.51178/jetl.v2i3.67

Sophia Azhar. (2017). Leadership Of The Head Of Effective School ( Islamic Education Perspective ). Auladuna: Jurnal Pendidikan Dasar Islam, 4(1), 20-29. https://doi.org/https://doi.org/10.24252/auladuna.v4i1a3.2017

Syafaruddin. (2008). Efektifitas Kebijakan Pendidikan. Rineka Cipta.

Wakhudin Dkk. (2020). Covid-19 Dalam Ragam Tinjauan (Didik Haryadi Santoso dan Awan Santosa (ed.); pertama). MBridge https://scholar.google.co.id/scholar?hl=id\&as_sdt=0\%2C5\&q=Covid19+Dalam+Ragam+Tinjauan\&btnG=

Yeni Rachmawati. (n.d.). Perkembangan Sosial Emosional pada Anak Usia Taman Kanakkanak. In Modul 1 PAUD.

Yuli Dwi Indahwati. (2018). Strategi Kepala Sekolah Dalam Pengembangan Kompetensi Profesional Guru Untuk Meningkatkan Mutu Pendidikan di MA Hidayatul Mubtadiin Tasikmadu Lowokwaru - Malang [Pascasarjana Universitas Islam Negeri Maulana Malik Ibrahim Malang]. http://etheses.uin-malang.ac.id/id/eprint/10267

Zhou, L., Wu, S., Zhou, M., \& Li, F. (2020). 'School's Out, But Class' On', The Largest Online Education in the World Today: Taking China's Practical Exploration During The COVID-19 Epidemic Prevention and Control As an Example. SSRN Electronic Journal. https://doi.org/10.2139/ssrn.3555520 